\title{
〔第44回総会シンポジウム 一診療用放射線の安全管理一〕
}

\author{
座長 集 約 \\ 菊 地透 \\ 自治医科大学 RI センター
}

今日の放射線診療技術における放射線利用には目ざま しい発展と普及があり, 今後も益々発展することと確信 している.しかし，医療領域における放射線防護・安全 管理に関しては，さまざまな諸問題が未解決のまま内在 しており, それらの問題解決は多くの関係者によって, 機会あるごとに指摘されながらも, 顕著化されないで何 とか今日まで行われてきた感がある，今後も，このまま の現状で何とか医療の放射線防護・安全管理がやってい けるかと考えると，大変悠しい状況にある。

特に, 診療用放射線の利用は, 放射線防護の観点から すれば，意図的に人体，患者に直接放射線を被曝させる 特殊な利用方法である。このような放射線利用は, 他の 領域の放射線利用目的とは異なり, 医療領域の放射線利 用が, 医療以外の領域の放射線利用とは異なる特殊な事 情があることを考えると，医療領域の放射線管理のあり 方, 考え方を医療の内部から改善していくことを真剣に 検討しなければならない時期と考えている.

また，今回の ICRP 勧告26の放射線防護関係法令への 取入れにより，医療法施行規則をはじめ放射線障害防止 法等の大幅な改正が行われ, 昭和 64 年 4 月から施行され る.このような時期に, 当シンポジウムを開催すること は，医療領域における放射線管理を見直す大変よい夕イ ミングと考えている.

本学会を含め医療放射線関連諸学会では, 放射線利用 には多大の関心をもつているが，放射線管理に対する関 心は高いとは言えない，このために，医療の放射線管理 は歴史的には古いが, 多くの医療現場では, いまだに片 手間の放射線管理が行われ，他の放射線領域から比べる と明らかに見劣りする。

しかし, 今日の医療を取り巻く環境は厳しく, 今後さ らに放射線診療を進展させ，国民の健康・福祉に賁献さ せて行く上で，放射線管理は必要不可欠な条件と考えて いる，そのためにも，このシンポジウムを契機に，今後 は医療における放射線管理に新たな関心が寄せられ，放 射線診療の新分野として確立し，質的向上を図ることが, 放射線診療に大きく貢献すると確信している.

\section{1. 管理のための卒前教育（折戸）}

医療領域における放射線安全管理を向上するためには, 医療従事者に対する卒前の放射線安全教育の充実が重要 である、しかし, 医師, 看護婦等の卒前教育においては, 不十分であるとの指摘がある.今回は，とくに放射線診 療の中心的役割を担う, 診療放射線技師の放射線防護教 育に関する卒前教育の現状を分析するために, 全国29校 の放射線技師教育機関に対してのアンケート調査結果か ら，その果たす役割を報告している.

放射線防護・管理に直接関係する科目は, 放射線管理 学 (30時間), 同実験 (45時間), 放射線衛生学 (15時 間), 関係法規 (30時間) がある. その他に, 放射線計測 学, 放射線の物理・生物・化学, 放射線機器工学等も管 理に関係する内容が多く含まれている，また，各校自由 に使う 500 時間の内，15時間から 120 時間が防護教育に使 用されている. しかし, 放射線管理科目の教官は, 他の 専門科目教官の掛持ちが多く, 放射線防護を専任とする 教官は少ない.今後さらに卒前教育の質を向上するため には, 教育機関側の改善が重要である. それにしても, 医療関係者の卒前教育でカリキュラム上, 最も充実して いるのは診療放射線技師である，最近，放射線技師の 4 年制大学も設置されており, 卒前の防護教育を卒後の医 療現場にもっと活用すべきである。

\section{2. 現場における安全教育（佐藤）}

医療の放射線利用現瑒において, 放射線安全教育の果 たす役割は大きい.しかし，大半の医療施設では，医療 法施行規則の適用のみで, 安全教育訓練の法的規制のあ る放射線障害防止法の適用を受けておらず，安全教育は 徹底されていないのが現状である。

放射線安全・管理は, 各現場の実状に対応した現場教 育 (On the Job Training) と日進月歩の放射線防護・ 管理技術教育が重要である. そのためには，積極的に病 院現場に即したカリキュラムを作成し，その中心的な役 割として, 診療放射線技師が適当と考える。しかし，例 
え主任者の資格を有する放射線技師が担当するにしても， 組織上の問題がある. 今後は, 主任者に対応した医療放 射線管理者の専門資格制度の導入が提案された。

\section{3. 病院における管理経験（伊勢）}

大学病院の放射線管理を担当し, 思考錯誤の中で行っ た管理経験を整理し，今後の病院の実践的な放射線管理 手法についていくつか示唆した. 放射線管理組織の見直 しとして，日中の放射線技師業務と夕方からの一人で悩 む管理時代から, 放射線管理の専門家の協力と助言, 複 数で相談しながら行う管理とした。現在は，専任者 1 名 に長期兼務者 3 名（1種主任者資格者） と，短期兼務者 3 名（1 年間）によって実務を担当している．短期兼務 者は，一般の放射線技師業務の修得業務として実施して いる。これにより，放射線技師が利用に関する能力ばか りでなく，放射線管理の能力についても合わせ持つべき との卒前教育思想が，現場に生かされることになった。

今後は, さらに病院における放射線管理の必要性と具 体的な管理業務を明確にするためにマニアルを作成中で ある.また，行政側の協力として，管理担当者の資格と 権限および研修制度等を整備する必要がある。

\section{4. 管理のための測定法（梅崎）}

病院の放射線管理のために用いられる放射線測定器と, 測定者の測定技術レベルには, 種々の問題が重なり測定 の信頼性に欠けている状況がある. 今回, 大学病院 125 施 設に対してのアンケート調査結果から, その現状を把握 し, 今回法令改正で導入された, 実効線量当量および $\mathrm{H}$ $1 \mathrm{~cm}$ 線量当量に対応した測定法について検討している. とくに, 大半の病院で利用しているX線診断領域の測定 に関しては, 空気吸収線量から $\mathrm{H} 1 \mathrm{~cm}$ 線量当量を換算す る場合, 低エネルギー領域の測定が重要である.

また，測定対象の状態についても，污染が乾燥か液体 状によって，3 倍の差があり, フィルムバッチの着用位 置によっては, 散乱線の寄与が50\%増加する. 医療で使 用されている放射線エネルギーは $10 \mathrm{keV}-30 \mathrm{MeV}$ ま で，多岐に渡り利用されているので，それに対応した医 療用測定器の開発を早急に検討する必要がある。

\section{5. 法令改正の対応（草間）}

今回 ICRP26勧告の法令への取入れにより，医療法施 行規則をはじめ, 放射線関係法令の大幅改正が，64年 4 月 1 日から施行される. 医療の放射線管理は, 法令主導 型として言われる. 改正の内容は, 単位, 線量評価, 健
康診断など技術的内容の改正が多く, 現場の管理担当者 に対して混乱が起きないように，医療の現場に対応する マニュアルが重要である，また，各自治体レべルで医療 監視員の指導が異なるために混乱があるので, 現在日本 保健物理学会の専門委員会において, 医療監視要綱のマ ニュアルと，現場放射線管理担当者用の管理マニュアル を作成中である。医療法施行規則の独自の改正としては, 放射性同位元素装備猃療器機, 治療室でのX線発生装置, $\mathrm{ICU}, \mathrm{CCU}$ 等での一時的な RI 使用などの新規項目が追 加され，医療の実態に合った厚生省の柔軟な対応が期待 できる。

\section{6. 安全管理の社会的意義（安斎）}

放射線は，発見と障害と利用と安全管理が，時を同じ くして以来, 放射線の利用とともに安全管理技術も格段 な進歩を遂げてきた。しかし，医療における放射線管理 において, ICRP 勧告の防護の原則に, 正当化, 最適化, 線量限度の 3 本柱の内, 患者被曝については線量限度が 除かれていること，および患者生命に関する緊急行為が, ややもすると正当化, 最適化も含め放射線管理をないが しろにする傾向が見受けられる。

今回は，患者の側から立って，放射線に対する意識(心 理)，放射線診療を検討するために，文科系学生を対象に アンケート調查を実施した．とくに我が国は, 広島, 長 崎, ビキ二の被災体験国として，放射線の心理的影響は， きわめて重要な問題である. 国民が必要とする放射線診 療の恩恵を正当に受けられる状況を維持するためには, 患者の放射線に対する不安を取り除き, 放射線管理のた ゆまざる努力に期待するところである。

\section{7. 総合討論}

コメンテイターとして砂屋敷先生（広大歯学部）から, 患者被曝の管理として, 被曝軽隇の重要性と, その測定 評価方法について実効線量当量が提案された. また, 古 賀先生（藤田保健衛生大） から， 4 年制大学の期待と, このシンポジウムを期して, 当学会としても放射線防護 委員会を設置して, 引続き検討され, 医療放射線関連学 会とし協力体制が必要と提案された.

その意味でも, 各演者の先生方は, その分野ですでに 活躍され，少なくとも今後も10年以上は現役として活動 される方々なので, 当学会が放射線防護の中心的な役割 を果たす分野として期待できる．また，会場には厚生省 の担当課の両課長補佐も参加され，厚生省の積極的な対 応が期待される，会場からのアンケートには，多くの放 
射線防護・管理に関する要望が記載され，会員の声とし て学会としても引続き検討される必要があり，放射線防 護委員会の設置を望む.このことは，放射線診療が真に
国民の健康増進に貢献する道と考えている。 最後に，この機会をタイミング良く与えて頂いた速水 学会長をはじめ役員諸氏に感謝します。 